\title{
The influence of alternaria black spot species on the oilseed rape infection development and intensity
}

\section{Wpływ patogenów wywołujących czerń krzyżowych na rozwój i natężenie infekcji rzepaku}

\author{
Agnieszka Perek $^{1 *}$, Katarzyna Pieczul $^{1}$, Agnieszka Dobrzycka $^{2}$, Joanna Wolko ${ }^{2}$
}

\section{Summary}

The aim of the study was to determine the rate of colonization of oilseed rape by selected species causing black spot of oilseed rape in order to determine their mutual influence on the development and intensity of the infection. Isolates of Alternaria alternata, Alternaria tenuissima, Alternaria brassicicola, Ulocladium chartarum and Cladosporium cladosporioides were used in the study. The plants were inoculated with spores of the listed species at various combinations. The intensity of the infection was evaluated 5,10 and 15 days after inoculation and the plant material was collected for mycological analysis. The most severe disease symptoms were caused by $A$. brassicicola, mainly in combination with $A$. tenuissima and $U$. chartarum. The symptoms of alternaria black spot of crucifers were also caused by $U$. chartarum and A. tenuissima species, which are not recognized as pathogens of oilseed rape. A. alternata infection caused weak disease symptoms. These results were confirmed by the mycological analyses.

Key words: Alternaria black spot; Alternaria spp.; oilseed rape; pathogenicity

\section{Streszczenie}

Celem pracy było określenie tempa kolonizacji rzepaku przez wybrane gatunki wywołujące czerń krzyżowych oraz określenie ich wzajemnego wpływu na rozwój i natężenie infekcji. W doświadczeniu wykorzystano izolaty Alternaria alternata, Alternaria tenuissima, Alternaria brassicicola, Ulocladium chartarum i Cladosporium cladosporioides. Rzepak inokulowano zarodnikami wyżej wymienionych gatunków w różnych kombinacjach. Po 5, 10 oraz 15 dniach od inokulacji dokonywano oceny porażenia roślin oraz pobierano materiał roślinny do analiz mikologicznych. Najsilniejsze porażenie roślin rzepaku wywoływał $A$. brassicicola, głównie w kombinacjach z A. tenuissima i U. chartarum. Objawy czerni krzyżowych wywoływane były także przez U. chartarum i A. tenuissima - gatunki nieopisywane dotychczas jako patogeny rzepaku oraz w niewielkim nasileniu przez A. alternata. Wyniki te znalazły potwierdzenie w przeprowadzonych analizach mikologicznych.

Słowa kluczowe: czerń krzyżowych; Alternaria spp.; rzepak; patogeniczność

\footnotetext{
${ }^{1}$ Instytut Ochrony Roślin - Państwowy Instytut Badawczy

Władysława Węgorka 20, 60-318 Poznań

2 Instytut Hodowli i Aklimatyzacji Roślin - Państwowy Instytut Badawczy

Strzeszyńska 36, 60-479 Poznań

*corresponding author: a.perek@iorpib.poznan.pl
} 


\section{Wstęp / Introduction}

Grzyby rodzaju Alternaria powodują choroby wielu gatunków roślin uprawnych, m.in. zbóż, roślin oleistych (rzepak, rzepik), warzyw (kalafior, brokuły, marchew, ziemniak, burak) oraz owoców (pomidory, papryka, jabłka, cytrusy) (Thomma 2003; Kirk i wsp. 2008). Patogeny te mogą porażać rośliny we wszystkich stadiach rozwojowych wywołując m.in. zgorzele siewek, choroby liści, nasion, a także zgnilizny owoców lub organów zapasowych rozwijające się w trakcie przechowywania. Alternaria jako patogen wtórny często pojawia się na roślinach osłabionych przez czynniki biotyczne lub abiotyczne, powszechnie spotykany jest na rozkładających się tkankach roślinnych oraz w glebie (Conn i wsp. 1990; Thomma 2003; Tylkowska i wsp. 2007).

W Polsce wśród głównych patogenów wywołujących czerń krzyżowych rzepaku wymieniane są trzy gatunki: Alternaria brassicae, Alternaria brassicicola oraz Alternaria alternata (Jajor i Korbas 2012). Patogeny te mogą porażać rzepak osobno lub wywoływać infekcje mieszane. Poszczególne gatunki różnią się nieznacznie zakresem temperatur preferowanych do rozwoju (Kumar i wsp. 2014), co w polskich warunkach klimatycznych może przyczyniać się do częstszego występowania $A$. brassicae. Wyżej wymienionym gatunkom często towarzyszą inne grzyby z rodzajów: Alternaria, Ulocladium, Botrytis, Embellisia, Cladosporium - sa to gatunki saprotroficzne lub słabe patogeny niektórych gatunków roślin (Butler i wsp. 1979; Demirci i Döken 1989; Schubert 2005; Woudenberg i wsp. 2015). Ich znaczenie w rozwoju czerni krzyżowych rzepaku nie zostało definitywnie wyjaśnione.

Celem pracy było określenie wzajemnego wpływu wybranych gatunków grzybów wywołujących czerń krzyżowych oraz gatunków saprotroficznych na rozwój i natężenie infekcji roślin rzepaku.

\section{Materiały i metody / Materials and methods}

Izolaty. W doświadczeniu wykorzystano izolaty grzybów: A. alternata (sekcja Alternata), A. tenuissima (sekcja Alternata), A. brassicicola (sekcja Brassicicola), Ulocladium chartarum syn. Alternaria chartarum (sekcja Pseudoulocladium) i Cladosporium cladosporioides. Kultury grzybów izolowane były w latach 2015-2016 z porażonych roślin rzepaku, pochodzących z pól uprawnych zlokalizowanych na terenie województwa wielkopolskiego. Gatunki badanych izolatów zostały oznaczone na podstawie cech morfologicznych makro- i mikroskopowych (Simmons 2007). Identyfikacja morfologiczna została potwierdzona przez analizę sekwencji rybosomalnego DNA (deoxyribonucleic acid) (rejon ITS1 - 5,8 rDNA - ITS2).

Analiza genetyczna. Do izolacji genomowego DNA wykorzystano świeżą grzybnię każdego z izolatów, hodowaną w temperaturze pokojowej przez 10 dni na stałej pożywce PDA (Potato Dextrose Agar; Difco). Fragmenty grzybni starannie odseparowano od pożywki i zhomogenizowano. Izolację DNA przeprowadzono przy użyciu zestawu „DNeasy Plant Mini Kit” (Qiagen) według protokołu producenta. Wydajność izolacji DNA zmierzono spektro- fotometrycznie. Z wszystkich prób przygotowano rozcieńczenia DNA o stężeniu $30 \mathrm{ng} / \mu \mathrm{l}$. Mieszanina reakcyjna o końcowej objętości 12,5 $\mu \mathrm{l}$ zawierała: 0,2 $\mu 110 \mathrm{mM}$ starterów ITS 1 i ITS 4 (White i wsp. 1990), $1,25 \mu \mathrm{l}$ $10 \times$ buforu Dream Tag (Thermo Fisher Scientific), 0,25 $\mu \mathrm{l}$ $200 \mu \mathrm{M}$ dNTP mix (Thermo Fisher Scientific), 0,05 $\mu 15 \mathrm{U}$ Dream Taq DNA polimerazy (Thermo Fisher Scientific), $1,5 \mu \mathrm{l}$ roztworu DNA o stężeniu $30 \mathrm{ng} / \mu \mathrm{l}$. Zastosowany został następujący profil termiczny reakcji PCR (polymerase chain reaction): wstępna denaturacja przez $4 \mathrm{~min}$. w $95^{\circ} \mathrm{C}$; 39 cykli obejmujących denaturację $40 \mathrm{~s} \mathrm{w} 94^{\circ} \mathrm{C}$, hybrydyzację starterów $40 \mathrm{~s}$ w $50^{\circ} \mathrm{C}$, elongację $90 \mathrm{~s}$ w $72^{\circ} \mathrm{C}$; końcową elongację 5 min. w $72^{\circ} \mathrm{C}$. Rozdział elektroforetyczny prowadzono $\mathrm{w}$ buforze $1 \times \mathrm{TBE}$ przy napięciu $60 \mathrm{~V}$ w 2\% żelu agarozowym (Basica LE GQT; Pronat) barwionym Midori Green (Nippon). Analizie sekwencyjnej (dideoksy Sangera) poddano fragment DNA kodujący białka podjednostki rybosomalnej 5,8S rDNA oraz niekodujących regionów ITS 1 i ITS 2. Sekwencje badanych izolatów porównywane zostały z danymi zawartymi w bazie GeneBank, na podstawie których potwierdzono ich identyfikację gatunkową (http://www.ncbi.nlm. nih.gov/BLAST/). Analizę podobieństwa filogenetycznego sekwencji DNA badanych izolatów oraz sekwencji izolatów referencyjnych wykonano w programie MEGA 6 stosując funkcję Neighbor Joining (rys. 1).

Materiał roślinny. W badaniach wykorzystano rośliny rzepaku odmian: Monolit, Mendel, Polka oraz żółtonasienną linię 1425 (charakteryzującą się podwyższoną zawartością oleju i białka oraz niską zawartością błonnika w nasionach w porównaniu do linii z czarnymi nasionami).

Testy infekcyjne. Doświadczenie przeprowadzono w szklarni, w temperaturze $26-28^{\circ} \mathrm{C}$ w dzień oraz $14-16^{\circ} \mathrm{C}$ w nocy. Do doniczek o pojemności $280 \mathrm{~cm}^{3}$ wypełnionych podłożem ogrodniczym ( $\mathrm{pH}$ 6,0-6,8; Kronen) wysiewano po 10 nasion badanych odmian i linii. Po 40 dniach od skiełkowania w doniczkach pozostawiono po 5 zdrowych roślin. Doniczki każdej odmiany i linii podzielono na 10 grup (po 3 doniczki w grupie). Każdą roślinę z poszczególnej grupy inokulowano $1 \mathrm{ml}$ zawiesiny zarodników o stężeniu $0,5 \times 10^{6}$ lub $1 \mathrm{ml}$ mieszaniny zarodników złożonej z dwóch gatunków (w równych proporcjach) tworząc następujące kombinacje:

1. A - A. brassicicola

2. D - U. chartarum

3. E - A. alternata

4. F-C. cladosporioides

5. $\mathrm{G}-$ A. tenuissima

6. $\mathrm{A}+\mathrm{D}-($ A. brassicicola + U. chartarum $)$

7. $\mathrm{A}+\mathrm{E}-($ A. brassicicola + A. alternata $)$

8. $\mathrm{A}+\mathrm{F}-($ A. brassicicola + C. cladosporioides $)$

9. $\mathrm{A}+\mathrm{G}-($ A. brassicicola + A. tenuissima $)$

10. Kontrola (rośliny opryskiwane $1 \mathrm{ml}$ wody destylowanej)

W celu utrzymania wysokiej wilgotności przez pierwsze 5 dni od momentu inokulacji rośliny umieszczone były w przeźroczystych workach foliowych. Rozwój objawów chorobowych oceniano po 3, 5, 10 i 15 dniach od momentu inokulacji. 
Analiza mikologiczna. Po 5, 10 oraz 15 dniach od momentu inokulacji z każdej kombinacji pobierano po 5 liści z objawami chorobowymi w postaci plam lub nekroz. Pozyskane liście były dokładnie myte woda i suszone sterylną ligniną. $\mathrm{Z}$ pogranicza zdrowej i chorej tkanki wycinano dwa, losowo wybrane fragmenty liścia. Fragmenty te odkażano przez 40 sekund $\mathrm{w}<5 \%$ roztworze podchlorynu sodu (ACE; Procter \& Gamble), płukano w wodzie destylowanej i suszono na sterylnej bibule. Skrawki liści wykładano na płytki Petriego $(90 \mathrm{~mm}) \mathrm{z}$ pożywką PDA. Po 10-14 dniach hodowli kultur w temperaturze pokojowej liczono wyrastające kolonie grzybów oraz oznaczano ich gatunek na podstawie analizy morfologicznej grzybni oraz mikroskopowej zarodników konidialnych (Simmons 2007).

\section{Wyniki i dyskusja / Results and discussion}

Do głównych sprawców czerni krzyżowych zalicza się trzy gatunki: A. brassicicola, A. brassicae i A. alternata. $\mathrm{Z}$ roślin rzepaku często izolowane są także inne gatunki należące do rodzajów: Alternaria, Ulocladium, Embellisia, których znaczenie w rozwoju czerni krzyżowych jest pomijane. Jedną z przyczyn tego zjawiska są m.in. kłopoty z jednoznaczną identyfikacją gatunkową grzybów z rodzaju Alternaria. Ze względu na podobieństwa morfologiczne zarodników konidialnych oraz duży zakres roślin gospodarzy, prawidłowe oznaczenie niektórych gatunków tego rodzaju wyłącznie na podstawie cech morfologicznych jest trudne (Woudenberg i wsp. 2013). Badania genetyczne prowadzone $\mathrm{w}$ ostatnich latach pozwolity na ocenę różnorodności genetycznej rodzaju Alternaria. Przyczyniły się także do zmian w systematyce tego rodzaju, wprowadzając m.in. podział na sekcje (skupiające w swym obrębie gatunki o bliższym stopniu podobieństwa genetycznego) oraz zmiany pozycji systematycznej wielu gatunków (Lawrence i wsp. 2013; Woudenberg i wsp. 2013, 2015). Wprowadzenie cech genetycznych do systematyki grzybów prawdopodobnie przyczyni się do lepszego poznania składu gatunków Alternaria porażających lub zasiedlających rzepak. W niniejszej pracy do badań patogeniczności wybrane zostały izolaty pozyskane wyłącznie z porażonych roślin rzepaku. Były to zbliżone genetycznie i morfologicznie izolaty $A$. alternata i A. tenuissima (sekcja Alternata), A. brassicicola (sekcja Brassicicola), U. chartarum syn. A. chartarum (sekcja Pseudoulocladium) oraz gatunek rodzaju Cladosporium - C. cladosporioides (rys. 1). Gatunki A. tenuissima i U. chartarum nie były dotychczas opisywane jako patogeny mogące wywoływać czerń krzyżowych. W prowadzonych badaniach identyfikacja izolatu $A$. tenuissima, ze względu na brak cech morfologicznych umożliwiających jednoznaczną identyfikację tego gatunku, została oparta o analizę genetyczną.

W przeprowadzonych testach infekcyjnych oceniano patogeniczność izolatów wymienianych jako podstawowe gatunki wywołujące czerń krzyżowych - A. brassicicola (A) i A. alternata (E), gatunków których znaczenie w rozwoju choroby nie zostało definitywnie wyjaśnione U. chartarum (D) i A. tenuissima (G) oraz gatunku uznanego za powszechnie występującego saprotrofa - C. cladosporioides (F). Pierwsze objawy chorobowe w postaci drobnych, brunatnych plam obserwowano na liściach rzepaku już po trzech dniach od momentu inokulacji. Wystapiły one na wszystkich odmianach traktowanych izolatem A. brassicicola (A) oraz jego kombinacjach $\mathrm{z}$ innymi gatunkami $(\mathrm{A}+\mathrm{D}, \mathrm{A}+\mathrm{E}, \mathrm{A}+\mathrm{F}$, $\mathrm{A}+\mathrm{G})$. Po pięciu dniach od momentu inokulacji objawy chorobowe na liściach roślin inokulowanych A. brassicicola (A) powiększały się i zwiększały swoją liczebność, dodatkowo nieliczne plamy obserwowane były na ogonkach liściowych. Nieliczne, brunatne plamy obserwowano także na roślinach odmiany Mendel i Polka inokulowanych izolatem A. tenuissima (G). Po 10 dniach od momentu inokulacji na wszystkich obiektach traktowanych izolatem A. brassicicola (A) oraz zawierających go kombinacjach $(A+D, A+E, A+G, A+F)$ obserwowano dalszy rozwój typowych objawów czerni krzyżowych. Plamy chorobowe ulegały powiększeniu i obejmowały swym zasięgiem oprócz liści, także ogonki liściowe i łodygi roślin. Warto odnotować, iż nasilenie objawów chorobowych w grupach inokulowanych mieszaniną gatunków A. brassicicola i A. tenuissima $(\mathrm{A}+\mathrm{G})$ oraz A. brassicicola i $U$. chartarum $(\mathrm{A}+\mathrm{D})$ było silniejsze, niż $\mathrm{w}$ grupie inokulowanej wyłącznie izolatem A. brassicicola (A). Oprócz sympto-

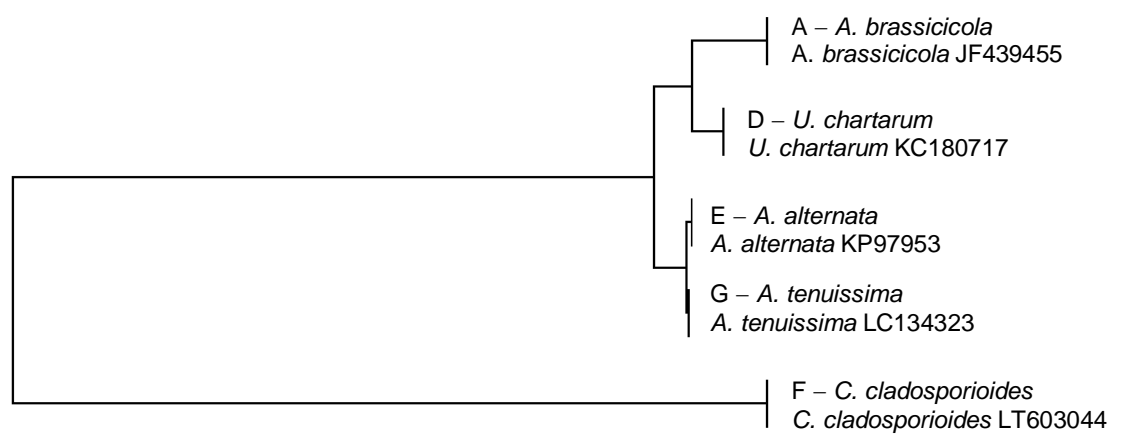

0.05

Rys. 1. Analiza podobieństwa genetycznego (Neighbor Joining) badanych izolatów wraz z izolatami referencyjnymi (NCBI)

Fig. 1. Analysis of genetic similarity (Neighbor Joining) of the tested isolates with the reference isolates (NCBI) 
mów typowych dla czerni krzyżowych w wyżej wymienionych kombinacjach obserwowano także całkowite zamieranie fragmentów liści i całych liści. Objawy chorobowe (słabsze, niż w przypadku inokulacji A. brassicicola) występowały również na roślinach wszystkich badanych odmian inokulowanych izolatami $A$. alternata (E), A. tenuissima (G) oraz U. chartarum (D). Powstające na liściach plamy były podobne do tych wywoływanych przez A. brassicicola, nie były one jednak tak ciemne, a ich margines był nieco rozmyty. Niewielkie, pojedyncze, ciemne plamy obserwowano na roślinach inokulowanych C. cladosporioides (z wyjątkiem odmiany Monolit). Na roślinach kontrolnych nie obserwowano porażenia roślin. Po 15 dniach od inokulacji rośliny inokulowane izolatem A. brassicicola (A), A. tenuissima (G), kombinacje A + G (A. brassicicola z A. tenuissima) oraz A + D (A. brassicicola z $U$. chartarum) charakteryzowały się silnym zniszczeniem tkanek inokulowanych liści, na których powierzchni rozwijały się kolonie innych gatunków grzybów saprotroficznych. Na roślinach pozostałych kombinacji $(\mathrm{E}, \mathrm{F}, \mathrm{A}+\mathrm{E}, \mathrm{A}+\mathrm{F})$ następował dalszy, stopniowy rozwój objawów chorobowych.

Według niektórych autorów gatunkami najczęściej porażającymi rzepak w Polsce są A. brassicae i A. alternata (Jajor i Korbas 2012). Inne badania wskazują, że A. brassicicola częściej niż A. brassicae izolowany jest z porażonych nasion warzyw (Köhl i wsp. 2010). Na podstawie przeprowadzonych badań do gatunków wywołujących czerń krzyżowych zaliczyć można także $A$. tenuissima oraz U. chartarum. W prowadzonych testach infekcyjnych obydwa izolaty charakteryzowały się silniejszą patogenicznością, niż uznawany za częstego patogena rzepaku A. alternata. Wynik ten może wskazywać, że w wykonanych badaniach wykorzystany był słabo patogeniczny szczep A. alternata. Potwierdza to doniesienia, że gatunek A. alternata zawiera zarówno szczepy silnie oraz słabo patogeniczne (Marcinkowska 2003; Thomma 2003; Woudenberg i wsp. 2013). Z drugiej strony nie jest jednak wykluczone, że wysoka częstotliwość, z jaką A. alternata jest izolowany $\mathrm{z}$ liści, łuszczyn lub nasion rzepaku może odzwierciedlać jego zdolność do kolonizowania tkanek wcześniej porażonych przez inne patogeny rodzaju Alternaria. Poszczególne gatunki rodzaju Alternaria wytwarzają różne typy szkodliwych metabolitów, o odmiennym mechanizmie działania na komórki roślinne, które w przypadku infekcji mieszanej mogą wzmagać swoje działanie (Logrieco i wsp. 2009). W warunkach polowych na wspólne oddziaływanie poszczególnych gatunków może wpływać także temperatura, dostępność inokulum patogenów, podatność odmian lub prowadzona ochrona chemiczna, eliminująca gatunki bardziej wrażliwe na stosowane fungicydy.

Do badań mikologicznych pobierano jedynie liście z widocznymi objawami chorobowymi. W terminie pierwszym badaniami objęto liście wszystkich odmian i linii inokulowanych izolatem A. brassicicola (A), jego kombinacjami $(A+D, A+E, A+G, A+F)$ oraz liście odmian Mendel i Polka inokulowanych izolatem A. tenuissima $(\mathrm{G})$. Ze wszystkich prób roślin inokulowanych izolatem A. brassicicola (A), kombinacji A. brassicicola i A. alternata $(\mathrm{A}+\mathrm{E})$ oraz A. brassicicola i C. cla- dosporioides $(\mathrm{A}+\mathrm{F})$ wyosobniono wyłącznie kolonie A. brassicicola. $\mathrm{Z}$ prób roślin inokulowanych mieszaniną A. brassicicola z U. chartarum (A + D) oraz z A. tenusssima $(\mathrm{A}+\mathrm{G})$ uzyskano kolonie obydwu gatunków. Gatunkiem dominującym zasadniczo pozostawał A. brassicicola, w niektórych kombinacjach proporcje liczbowe kolonii obydwu gatunków były zbliżone (A $+\mathrm{D}$ odmiana Polka oraz A + G odmiana Monolit) lub nieznacznie dominował inny gatunek ( $\mathrm{A}+\mathrm{G}$ odmiana Mendel). Kolonie A. tenussima wyodrębniono ponadto $\mathrm{z}$ porażonych fragmentów roślin odmian Mendel i Polka inokulowanych wyłącznie tym gatunkiem (kombinacja G). Izolat $U$. chartarum wyizolowano jedynie $\mathrm{z}$ prób łączących ten gatunek z A. brassicicola (A + D). Izolat A. alternata (E) oraz izolat C. cladosporioides (F) nie były izolowane, także z kombinacji A + E oraz A + F (tab. 1). W drugim terminie poboru prób izolaty A. brassicicola nadal izolowane były $\mathrm{z}$ wszystkich roślin traktowanych tym gatunkiem (A) oraz jego kombinacji (A + D, A + E, A + G, A + F). W kombinacjach A. brassicicola z U. chartarum $(\mathrm{A}+\mathrm{D})$ oraz A. brassicicola z A. tenusssima $(\mathrm{A}+\mathrm{G})$ w porównaniu z pierwszym terminem obserwowano jednak istotne zmiany $\mathrm{w}$ proporcjach kolonii uzyskanych $\mathrm{z}$ porażonych fragmentów roślin. Izolat $U$. chartarum izolowany był z podobną częstotliwością, jak $A$. brassicicola, podczas gdy A. tenuissima był gatunkiem izolowanym częściej niż A. brassicicola. Wyniki te mogą wskazywać, że gatunki te preferują kolonizację tkanek wcześniej uszkodzonych przez silniejsze patogeny. Analiza mikologiczna gatunków wyodrębnionych z kombinacji A. brassicicola z A. alternata (A + E) oraz A. brassicicola z C. cladosporioides (A + F) wskazywała, że A. brassicicola pozostawał gatunkiem dominującym. Dopiero po 10 dniach od inokulacji z roślin traktowanych izolatami U. chartarum (D), A. alternata (E) i A. tenuissima (G) uzyskano odpowiednio kolonie wymienionych gatunków. Wskazuje to na znacznie wolniejsze tempo porażania roślin rzepaku w porównaniu z A. brassicicola. Z prób roślin inokulowanych izolatem $C$. cladosporioides wyosobniono przede wszystkim kolonie innych gatunków, co świadczyło o zasiedlaniu roślin w tej kombinacji przez obecne w otoczeniu patogeny i saprotrofy. Po 15 dniach od momentu inokulacji do analizy mikologicznej pobrano materiał jedynie $\mathrm{z}$ kombinacji zawierających izolaty U. chartarum (D), A. alternata (E), C. cladosporioides (F) oraz kombinacji A + E i A + F. Z wyżej wymienionych prób izolowano zarówno gatunki badane, jak i inne wskazujące na stopniowe zasiedlanie tkanek przez obecne w otoczeniu grzyby saprotroficzne. Pozostałe próby charakteryzował silny rozkład tkanek liści oraz masowe zasiedlenie przez gatunki saprotroficzne z rodzajów Penicillium i Botrytis, uniemożliwiające prawidłową analizę wzajemnego oddziaływania badanych gatunków.

Uzyskane wyniki analiz mikologicznych potwierdzają, że $A$. brassicicola należy do patogenów porażających rzepak szybciej niż inne badane gatunki. Pozostałe badane gatunki charakteryzowały się wolniejszym tempem kolonizacji roślin rzepaku, choć częstość ich izolacji wzrastała $\mathrm{w}$ trakcie postępowania infekcji. Wśród grzybów zasiedlających liście i łuszczyny rzepaku często wymienia się C. cladosporioides, jednak zazwyczaj występuje on w nie- 


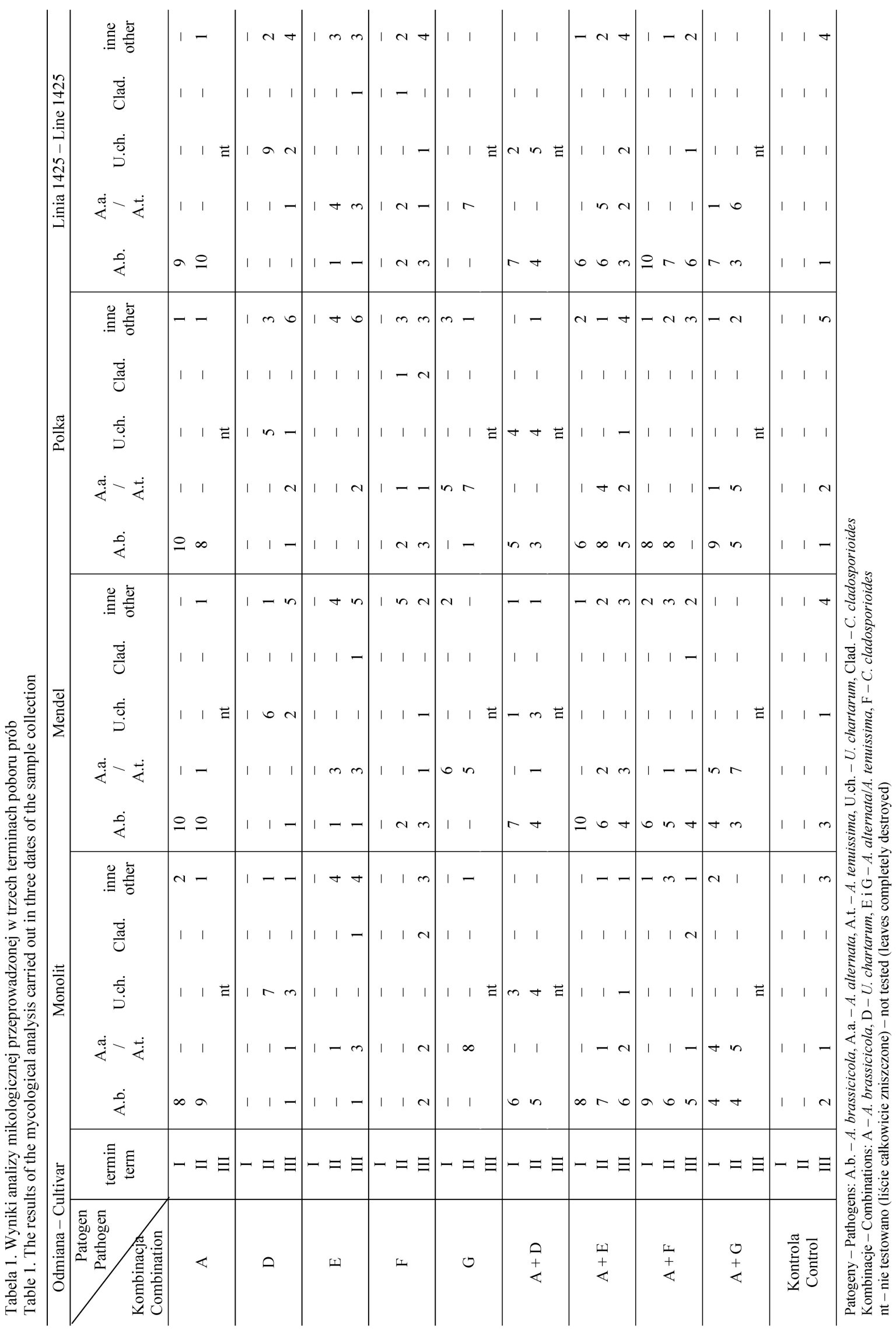


wielkim nasileniu (Pusz 2007). W przeprowadzonych badaniach gatunek ten nie wywoływał objawów chorobowych, izolowany był $w$ niewielkich ilościach jedynie z liści pobranych po 15 dniach od momentu inokulacji. Nie jest wykluczone, że znalazł się on jednak na roślinach w wyniku wtórnego zasiedlania martwych tkanek.

\section{Wnioski / Conclusions}

1. Najsilniejsze porażenie roślin rzepaku obserwowano w kombinacjach gatunków A. brasicicola z A. tenuissi- ma oraz A. brassicicola z U. chartarum, co może wskazywać na współdziałanie izolatów w infekowaniu roślin.

2. Objawy czerni krzyżowych w sprzyjających warunkach mogą być wywoływane przez inne gatunki, jak U. chartarum i A. tenuissima, nie opisywane dotychczas jako patogeny rzepaku.

3. Izolat A. alternata wywoływał słabe porażenie roślin, choć gatunek ten wymieniany jest wśród podstawowych patogenów wywołujących czerń krzyżowych.

\section{Literatura / References}

Butler D., Griffin M.J., Fletcher J.T. 1979. Leaf spot on cucumber caused by Ulocladium atrum. Plant Pathology 28 (2): $96-97$.

Conn K.L., Tewari J.P., Awasthi R.P. 1990. A disease assessment key for Alternaria black spot in rapeseed and mustard. Canadian Plant Disease Survey 70 (1): 19-22.

Demirci E., Döken M.T. 1989. Studies on the determination and identification of fungal agents of the diseases isolated from the roots, stems and leaves of potatoes in Erzurum region. Journal of Turkish Phytopathology 18 (1-2): 51-60.

Jajor E., Korbas M. 2012. Występowanie grzybów z rodzaju Alternaria w liściach i łuszczynach rzepaku z objawami czerni krzyżowych. Rośliny Oleiste - Oilseed Crops 33 (2): 185-200.

Kirk P.M., Cannon P.F., Minter D.W., Stalpers J.A. 2008. Dictionary of the Fungi. 10th ed. CABI, Wallingford, 22 pp.

Köhl J., van Tongeren C., Groenenboom-de Haas B.H., van Hoof R.A., Driessen R., van der Heijden L. 2010. Epidemiology of dark leaf spot caused by Alternaria brassicicola and A. brassicae seed production of cauliflower. Plant Pathology 59 (2): 358-367.

Kumar D., Maurya N., Bharati Y.K., Kumar K., Srivastava K., Chand G., Kushwaha C., Singh S.K., Mishra R.K. 2014. Alternaria blight of oilseed Brassicas: A comprehensive review. African Journal of Microbiology Research 8: 2816-2829.

Lawrence D.P., Gannibal P.B., Peever T.L., Pryo B.M. 2013. The sections of Alternaria: formalizing species-groups concepts. Mycologia 105 (3): 530-546.

Logrieco A., Moretti A., Solfrizzo M. 2009. Alternaria toxins and plant diseases: An overview of origin, occurrence and risk. World Mycotoxin Journal 2: 129-140.

Marcinkowska J. 2003. Oznaczanie rodzajów grzybów ważnych w patologii roślin. Fundacja Rozwoju SGGW, Warszawa, 328 ss.

Pusz W. 2007. Wpływ obsady roślin w łanie na zdrowotność rzepaku ozimego. Zeszyty Naukowe Uniwersytetu Przyrodniczego we Wrocławiu, Rolnictwo XC, 553: 83-91.

Schubert K. 2005. Morphotaxonomic revision of foliicolous Cladosporium species (hyphomycetes). Ph.D. dissertation. Martin-LutherUniversity Halle-Wittenberg, Germany.

Simmons E.G. 2007. Alternaria. An Identification Manual. CBS Fungal Biodiversity, Series No. 6, Utrecht, 775 pp.

Thomma B.P. 2003. Alternaria spp.: from general saprophyte to specific parasite. Molecular Plant Pathology 4 (4): $225-236$.

Tylkowska K., Dorna H., Szopińska D. 2007. Patologia nasion. Akademia Rolnicza, Poznań, 184 ss.

White T.J., Bruns T., Lee S., Taylor J. 1990. Amplification and direct sequencing of fungal ribosomal RNA genes for phylogenetics. p. 315-322. In: "PCR protocols: a guide to methods and applications" (M.A. Innis, D.H. Gelfand, J.J. Sninsky, T.J. White, eds.). Academic Press, San Diego, CA, USA.

Woudenberg J.H., Groenewald J.Z., Binder M., Crous P.W. 2013. Alternaria redefined. Studies in Mycology 75 (1): 171-212.

Woudenberg J.H., Seidl M.F., Groenewald J.Z., de Vries M., Stielow B., Thomma B.P., Crous P.W. 2015. Alternaria section Alternaria: Species, formae speciales or pathotypes? Studies in Mycology 82: 1-21. 